\title{
Historiens ironier
}

Man skal mangle sans for humor for ikke at kunne se ironien i den historie om Strukturkommissionen for Folkekirken 1964-1971, som Tine Reeh afdækker i nummerets første artikel. Kirkeminister Bodil Koch var hele vejen igennem overbevist om samdrægtigheden af folk og kirke, selvom den kirkesociologiske udredning viste på sprækkerne i den folkekirkelige konsensus. Samtidig påpegede den sociologiske rapport, at Folkekirken stod stærkt i de små landsogne; alligevel blev det resultatet af Strukturkommissionens arbejde, at de små sogne blev sammenlagt. DJØFiceringen satte åbenbart tidligt ind.

Men der er også en vis ironi indbygget i Ole Nyborgs minutiøse undersøgelse af Grundtvigs forkyndelse af næstekærlighed i prædikenerne fra 1832-1849 og 1855-56. Det har længe heddet sig, at Grundtvig efter 1832 opdagede det gode og naturlige fællesmenneskelige liv - og dermed lagde afstand til de andre vækkelser. Men som Nyborg viser, nærede Grundtvig ikke just nogen stor tillid til det "naturlige" menneske i prædikenerne. Tværtimod skal den kristne med sin faderlighed drage næsten "opad" - og dermed vække og forvandle medmennesket. Denne tanke om en nødvendig opdragelsesproces bringer til gengæld Grundtvig tættere på Kierkegaards pointer i Kjerlighedens Gjerninger. Her er stof til fremtidige undersøgelser.

Derimod er der ikke megen selvironi i den tyske "Rigsbiskop" Ludwig Müllers teologi. Her tales der om natur og kraft, så det batter, alt imens den kristne syndslære afbygges til ukendelighed til fordel for billedet af den vitale og selvofrende tysker. Der var som bekendt mange ikke-tyskere, der måtte bløde for denne tyske offervilje. Martin Friis' artikel er et memento til enhver samtidsteologi, der ikke vil være andet end samtidens talerør.

Til sidst bringer vi teologen Knud Hansens og psykologen Margit Hartyanis introduktion til Ludvig Feilbergs levelære. Feilbergs tanke om "intetfang" er blevet taget op af digteren Pia Tafdrup, ligesom forskellen mellem "ligeløb" og "kredsning" kan ses som en vejbereder for Løgstrups skelnen mellem suveræne og kredsende livsytringer. Men der også forskelle. For ifølge Feilberg er kredsningen ikke kun noget rent negativt, men har også positiv betydning for menneskets omtanke og overvejelse og for dets selvinvolverede samlethed og fatning. Samtidig gør Hansen og Hartyani gældende, at Feilbergs religiøse holdning ikke blot kan betegnes som panteistisk, men også havde stærke kristne rødder.

Fra redaktionen ønsker vi god fornøjelse med lesningen! Niels Henrik Gregersen 